\title{
Megaforma e \\ Mesgaestrutura: \\ categorias entre técnica, território \\ e lugar e sua pertinência na arquitetura brasileira
}

Victor Piedade de Próspero*

Resumo Este artigo buscará analisar as categorias Megaforma, de Kenneth Frampton, e Megaestrutura, de Reyner Banham, situando-as a partir da abordagem teórica de cada um desses historiadores da arquitetura. Entendemos como fundamental a leitura crítica e historicamente situada dessas categorias, tratando-as em relação a outros conceitos aos quais estas se referem, como as ideias de lugar e território, de modo a trazer a tona também os aspectos de dimensão política implicados em ambos os casos. A pertinência desses termos nas leituras historiográficas da arquitetura brasileira aparecerá também como importante objeto de reflexão.

Palavras-chave: megaforma, megaestrutura, território.

\section{Megaform and Megastructure:} categories between technique, territory and place and its relevance in brazilian architecture

\begin{abstract}
This article aims an analysis of the categories Megaform, by Kenneth Frampton, and Megastructure, by Reyner Banham, facing them by the theoretical approach of both architecture historians. It is central to make a critical and historically bounded reading of these categories, treating them concerning other concepts to which they refer, such as the ideas of place and territory, in a way to bring up also elements of a political dimension implied in it. The pertinence of both terms in Brazilian architecture historiography also appears as an essential object of reflection.
\end{abstract}

Key words: megaform, megastructure, territory.

\section{Megaforma y Megaestructura: categorías entre técnica, territorio y lugar y su pertinencia en la arquitectura brasileña}

Resumen Este artículo buscará analizar las categorías Megaforma, de Kenneth Frampton, y Megaestructura, de Reyner Banham, situándolas a partir del enfoque teórico de cada uno de esos historiadores de la arquitectura. Entendemos como fundamental la lectura crítica e históricamente situada de esas categorías, tratándolas en relación a otros conceptos a los que se refieren, como las ideas de lugary territorio, para traer a la luz también los aspectos de dimensión política en ambos casos. La pertinencia de estos términos en las lecturas historiográficas de la arquitectura brasileña aparecerá también como importante objeto de reflexión.

Palavras clave: megaforma, megaestructura, territorio. 
Dara o historiador e crítico Kenneth Frampton, uma diferença marcante entre a "cidade metropolitana" do século XIX e a "região urbanizada" do século XX estaria no caráter de não-lugar desta última e em sua ausência de marcos urbanos significativos. Forma assumida pelas cidades principalmente após a Segunda Guerra Mundial, quando a realidade universal passou a ser cada vez mais marcada por assentamentos infinitos, sub-urbanizados, chamamos de megalópole (FRAMPTON, 2008). Tratando dela, Frampton demonstra pouca esperança na capacidade efetiva do planejamento urbano de imposição sobre um processo que se estende à totalidade da superfície terrestre, crescentemente ocupada de modo alheio ao debate acadêmico, produzindo lugares culturalmente irrelevantes.

É a partir dessa constatação que Frampton cunha o termo Megaforma para designar um modo de atuação da arquitetura enquanto catalizador urbano, enquanto desenho da cidade por meio do edifício, de maneira pontual. A ideia enfatizada pelo autor é a de construção da paisagem urbana. Para isso, Frampton retomará ideias de Le Corbusier, Jaap Bakema e Vittorio Gregotti, no desenho de grandes estruturas que permeiam e delimitam o tecido urbano quase que por completo, para afirmar uma posição diferente, ainda que derivada dessas experiências de projeto: a ideia de arquitetura como "acupuntura urbana" ${ }^{1}$. Como projetos de edifícios, de variadas escalas, são capazes de construir a paisagem urbana? De criar um sentido de lugar, construindo o programa de modo integrado com espaços de uso indefinido, de modo articulado com os fluxos do tecido urbano?

A Megaforma seria marcada por algumas características básicas: a disposição horizontal dos edifícios, seu caráter topográfico, programático e a construção de marcos urbanos não pela via da monumentalidade, mas pela construção do lugar enquanto espaço de apropriação e de caráter cívico. Aqui, misturam-se aspectos da leitura dos programas e usos com aspectos da construção formal e de implantação dos edifícios. Frampton busca na horizontalidade dos edifícios sua consequente integração com a cidade. Entende por topográfica a característica de articulação que um projeto pode estabelecer na transição de níveis e escalas, entre rua e espaços internos. Trata-se, portanto, de um dispositivo que transita entre diferentes elementos qualitativos, mas

*Victor Piedade de Próspero é Arquiteto e Urbanista, dourotando pela Faculdade de Arquitetura e Urbanismo da USP. ORCID: $<$ https://orcid.org/0000-00027558-2610>

1 Aqui, Frampton se apropria do conceito de Manuel de Solà-Morales. SOLÀ-MORALES, Manuel de. De cosas urbanas. Barcelona: Editorial Gustavo Gili, 2008. que podem ser condensados e articulados entre si. Ao mesmo tempo, não é preciso dizer que a disposição horizontal não garantiria por si só a qualidade de catalizador urbano desejada pelo autor.

É possível aprofundar essas questões a partir de algumas análises de projetos feitas por Frampton para demonstrar como aspectos da construção da paisagem, presentes em Corbusier ou Bakema, estariam presentes em projetos de menor escala e extensão, como no caso do projeto de Alvar Aalto para o Baker Dormitory, em Cambridge. Colocadas estas questões, talvez seja igualmente sugestivo lançarmos um olhar para algumas experiências de projeto no Brasil, que se aproximam do que Frampton conceitua 
como Megaforma. Afinal, a produção moderna no país, especialmente, muitas vezes enveredou pelo propósito da construção da paisagem urbana por meio de edifícios com forte caráter topográfico, ainda que apontando para uma urbanidade um tanto específica. Diferente da inserção de "catalizadores urbanos" no tecido consolidado da cidade europeia, no Brasil o projeto moderno tinha como uma de suas premissas a construção de uma modernidade cultural associada ao desenvolvimento urbanoindustrial e à identidade nacional. Não por outra razão, tais megaformas brasileiras seriam em grande medida inseridas em contextos de baixa urbanização, ou ancoradas em padrões urbanísticos modernos, como a Carta de Atenas.

Os aspectos da construção do lugar, muito enfatizados por Frampton, se mostram fatores importantes em diversos casos brasileiros. Como nota Adrián Gorelik, sobre Brasília, os edifícios ali nasciam com a incumbência de construir um futuro e uma tradição, simultaneamente (GORELIK, 2005). A nova modernidade estaria marcada também pela necessidade de criar o /ugar, sem a necessidade de resgatar uma história. Não à toa, Frampton cita em diversos momentos exemplos da arquitetura brasileira ao debater seu conceito. O edifício da FAUUSP, de Villanova Artigas, ou projetos de Paulo Mendes da Rocha - dentre eles o Pavilhão de Osaka, o Poupa Tempo de Itaquera e o projeto para as Olimpíadas de Paris - são comentados pelo autor como exemplos de uma continuidade entre desenho das edificações e dos espaços públicos.

\section{Megaestruturas}

Ao olhar para a arquitetura brasileira por este viés é interessante lembrar de outro aspecto presente, levantado por alguns autores, que seria seu caráter megaestrutural. Guilherme Wisnik, por exemplo, define a arquitetura paulista, produzida a partir dos anos 1950 - frente à produção nacional - como marcada pela questão territorial e pelo caráter megaestrutural (WISNIK, 2003). Sem espanto, é comum ver Paulo Mendes da Rocha citar projetos de Kenzo Tange como referência (ARTIGAS, 2006). O projeto da Bahia de Tóquio, do arquiteto japonês, como se sabe, é um marco do pensamento megaestrutural e ao mesmo tempo de uma lógica de construção de infraestruturas visível em uma série de projetos do arquiteto brasileiro. Este projeto foi colocado por Reyner Banham lado a lado com o Plano Piloto de Brasília, para efeito de comparação e de demonstração de sua preferencia pela abordagem de Tange, que ofereceria uma solução tridimensional para o planejamento da cidade, por meio do desenho, definido

2 Tratando de Brasília, também compreende-se a preferencia de Paulo Mendes da Rocha pelo projeto apresentado por Rino Levi na ocasião do concurso para o Plano Piloto, solução que condensava grande parte do programa em edifícios verticais de grande escala estruturados entre si com torres de elevadores formando um conjunto megaestrutural.

30 termos teria sido trazido nos anos 1960 pela primeira vez por Fumihiko Maki e posteriormente apropriado por Banham. por um projeto de infraestruturas e de construção de um novo solo. ${ }^{2}$

Banham cunhou o termo Megaestrutura em seu livro de 1976², Megasctruture: Urban Futures of the Recent Past. Ali, o historiador inglês direciona seu olhar para uma vasta gama de projetos dos anos 1950 aos 1970 que têm como marca principal a expressividade da estrutura, a experimentação tecnológica e o caráter futurista e utópico dos projetos. Essas experimentações distanciavam-se do modernismo clássico, indo no sentido da afirmação da flexibilidade e do nomadismo, em alguns casos, ainda que fortemente marcadas pela "tecnotopia". De modo geral, entretanto, as megaestruturas consistiam, em quase todos os casos citados, em grandes estruturas que definiam totalidades, flexíveis ou não, implicando em intervenções radicais tanto como programa quanto na escala proposta. Dentro da trajetória teórica de Banham, este livro parece complementar os interesses do historiador, como demonstrados em "Teoria e Projeto na primeira era da máquina" (1975), em estabelecer novos 
Figura 1: Projeto para Bahia de Tokyo, Kenzo Tange, 1960. Fonte: TAFURI, M. DAL CO, F. Modern Architecture. parâmetros à crítica ao modernismo arquitetônico por não ter acompanhado de fato as potencialidades tecnológicas de sua época. As utopias futuristas tardias, após as décadas "heroicas" do modernismo, interessariam Banham por seu potencial experimental. Para ele, o caráter utópico das megaestruturas guardava em diversos casos um sentido anti-establishment, como promessa de superação da desordem e dos descontentamentos do passado, em favor de um novo mundo criado em sobrevoo, de alguma forma purificado da exaustão das civilizações abaixo. Se esta era a promessa, sua performance efetiva seria menos empolgante (BANHAM, 1976). Segundo Banham, "Megaestruturas, então, contêm alguns elementos de atavismo, uma retomada à 'era heroica da arquitetura moderna', e uma constante preocupação com o original movimento do futurismo italiano e croquis de Sant'Elia. Sem dúvida há uma nostalgia de um passado (e um futuro em hipótese) uma questão de gestos nítidos, sem os compromissos e diluições ou reduções de escala que corromperam a pureza e o radicalismo das intenções originais"(1976).

Já Manfredo Tafuri, ao comentar os projetos representativos de Megaestruturas procura demonstrar que "a tecnologia, como ocasião para diversão e espetáculo, tira de cena sonhos de reconstrução global de cidades e territórios, revive a determinação em efetivar a reconstrução futurista do universo, conclamada por Marinetti quase meio século antes. Com obstinação válida de uma causa maior, o desconhecido é novamente elevado a um mito; a vontade de forçar o presente é um indicador de

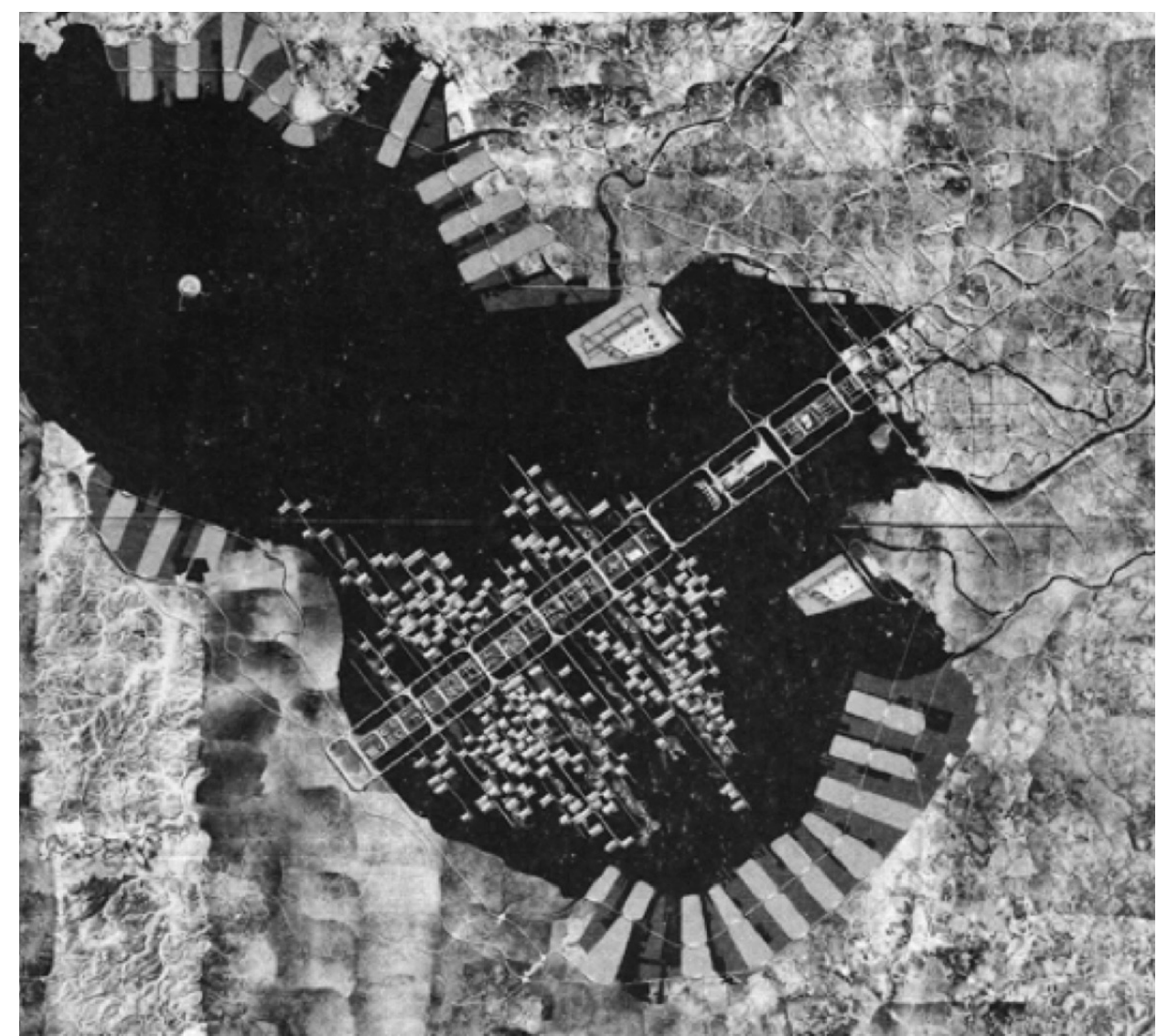


${ }^{4}$ A revista Acrópole mostra bem em alguns números, como as propostas de arquitetos para os concursos de projeto da época vinham marcadas por ideias megaestruturais. Ver números 369 e 361. Ver DEDECCA, Paula. Sociabilidade, crítica e posição. O meio arquitetônico, as revistas especializadas e o debate do moderno em São Paulo (19451965). Dissertação de mestrado. São Paulo: FAUUSP, 2012

\footnotetext{
${ }^{5}$ No capítulo "Architecture in the age of globalization: topography, morphology, sustainability, materiality, habitat and civic form 1975-2007" In. FRAMPTON, Kenneth. Modern Architecture, a critical history. Themes \& Hudson. World of Art. London. 2010.

60 termo utilizado no Inglês por Frampton é "space of public appearance", e encontrase assim também na tradução de Hannah Arendt para o português: ARENDT, Hannah. A condição humana. Tradução Roberto Raposo; Revisão técnica e apresentação Adriano Correia - 12. Ed. Rev. - Rio de Janeiro: Forense Universitária, 2016.
}

impotência" (1986). Para ele, ignoravam-se aspectos políticos do urbanismo radical dos anos 20 e 30, para contestá-lo apenas em termos tipológicos e formais, o que colaboraria para deixar essa nova geração de projetos à margem do planejamento como política, afirmando-se simplesmente como manifestações utópicas. A imagem de fracasso, no entanto, parecia, a Banham, uma medida equivocada da importância que a megaestrutura teve como promessa para uma geração. A partir de certo momento, segundo o autor, todo tipo de posicionamento político estaria contra a megaestrutura: ela teria sido condenada antes mesmo de acontecer (TAFURI; DAL CO, 1986). De todo modo, dada a força das imagens construídas por estes projetos, e também sua potência enquanto inovação - sem entrar no mérito também de seu caráter pop em um momento de criação de imagens de ficção científica - a Megaestrutura teria ampla difusão nessas décadas e marcaria também algumas experiências do modernismo brasileiro. $^{4}$

\section{Da Megaestrutura à Megaforma}

O caráter utópico e totalizante das Megaestruturas é fortemente contraposto pela busca de uma alternativa ao planejamento apresentada por Frampton ao propor o conceito de Megaforma. Para além de questões de escala e expressividade da estrutura, tratava-se de recuperar uma ênfase na articulação espacial, na construção do lugar, no caráter topográfico e na inserção dos edifícios no tecido.

Algumas ideias desenvolvidas durante a trajetória teórica de Kenneth Frampton parecem oferecer algumas premissas à elaboração da categoria de Megaforma. A leitura dos espaços inspirada no conceito de Hannah Arendt de esfera pública (1958), baseada também em Heidegger para o uso da noção de lugar. e, mais indiretamente, à leitura da tectônica na arquitetura. Alguns textos fundamentais do autor que desenvolvem estas ideias são "The status of man and the status of his objects"(1979), "Industrialization and the crises in architecture" (1972), "Uma Leitura de Heidegger" (1974), e "Studies in Tectonic Culture" (1995). Para além disso, toda a história da arquitetura feita por Frampton é marcada pelo viés composto por estes três pontos, como se pode ver em "Arquitetura Moderna, uma história crítica" (1980). Na trajetória do historiador, são marcos em sua busca por relacionar estética e política a leitura baseada na teoria crítica frankfurtiana a partir de Theodor Adrono e Walter Benjamin, e seu interesse inicial pelo construtivismo russo como momento chave na história da arquitetura moderna.

Em sua história crítica da arquitetura moderna ${ }^{5}$, Frampton aborda o tema da topografia, antes de chegar à categoria de Megaforma e, mais adiante, a ideia de forma cívica, como maneira de designar um conjunto de projetos. A forma cívica, para o autor, seria um meio de construir "espaços de aparência pública" ${ }^{6}$, no sentido arendtiano, frente a um cenário atual despolitizado. Esta ideia de Arendt aparece frequentemente também nas exposições sobre a Megaforma, assim como já apareceria desde o primeiro estudo de Frampton baseado nas ideias da filosofa alemã, "Industrualization and the crises in architecture", no qual o "espaço de aparência pública" serve ao autor para qualificar a experiência do construtivismo russo e sua potência de criação de signos e abertura de caminhos na política dentro daquele contexto histórico. Dessa forma, percebemos a importância dada pelo historiador a uma conexão entre as noções de forma e política, não pelo viés de desconstrução de signos, mas, pelo contrário, pela construção do lugar, associada à ideia de marco urbano enquanto espaço cívico, de 
Figura 2: Perspectiva da Universidade de Calábria, 1966. Fonte: COHEN, J. L. The Future of Architecture since 1889.

\footnotetext{
7 Para o arquiteto, há uma questão central de como dar forma ao território enquanto paisagem vivida. Em consequência interessa a ele alguns discutir a paisagem como objeto de sentido estético e a forma urbana de sua estruturação à sua apreensão. A paisagem teria papel fundamental na constituição da ideia de lugar, ao passo que é a referencia visual mais marcante na construção de sentido estético do território. Assim, na medida em que a paisagem é a cidade construída, Gregotti busca em abordagens como a de Kevin Lynch maneiras de ler a imagem da cidade para além de sua estrutura funcional. Assim, afirma haver interesse em um estudo semiológico das estruturas da cidade como linguagem, de uma "língua territorial", que teria papel de construção coletiva de sentido. Ver GREGOTTI, Vittorio. Território da Arquitetura. São Paulo. Perspectiva. 2010.
}

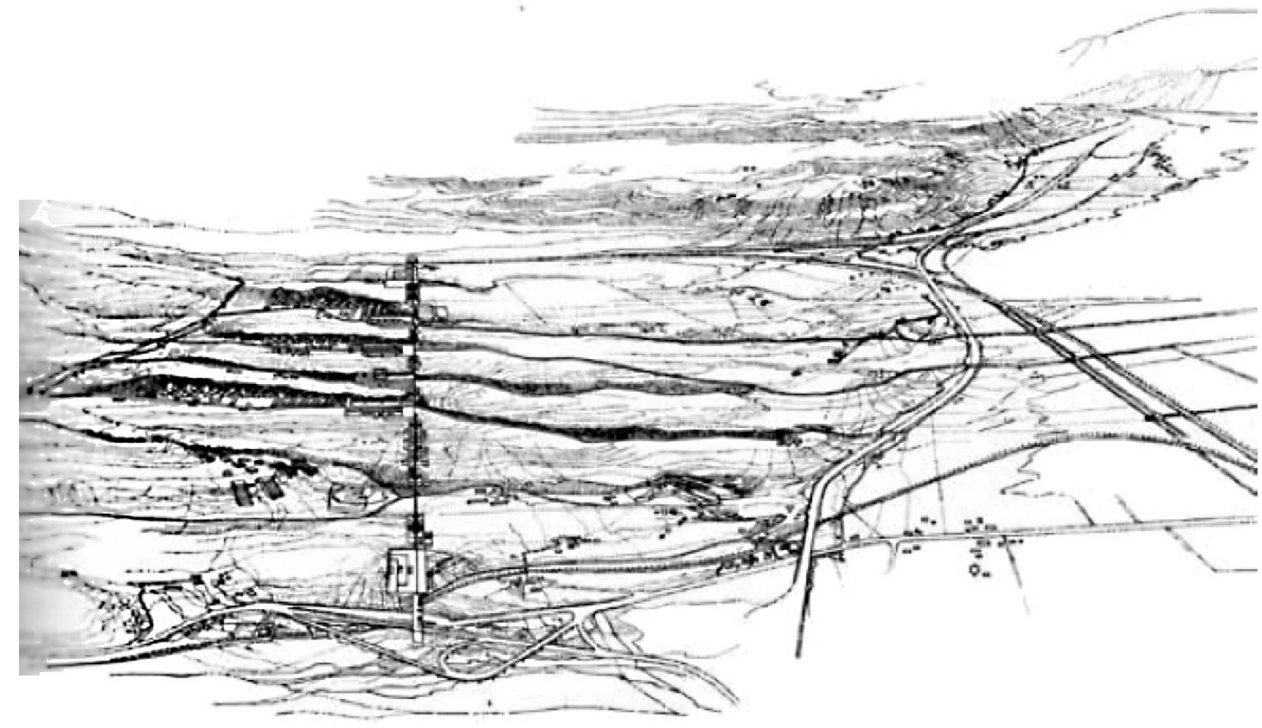

convivência e ação política. Assim, para Frampton, a forma arquitetônica parece ter papel central enquanto desenho potencializador de relações sociais.

Entre Megaforma e Megaestrutura, talvez Vittorio Gregotti seja uma referência singular que marcou o pensamento sobre o desenho da paisagem como projeto. Classificada por Manfredo Tafuri como uma "convivência entre cálculo totalizante e evasão quase surrealista" (1992), a obra de Gregotti visava a construção de uma imagem para a paisagem, dada pelo projeto e pelo desenho ${ }^{7}$. Tafuri enxergaria nessa abrangência do desenho, tanto de Gregotti como das Megaestruturas, um aspecto nostálgico com relação às utopias do início do século. A ideia de dar forma à paisagem partia de uma abordagem antropogeográfica, considerando uma "geografia humana" a ser construída (GREGOTTI, 1972). Os projetos abarcariam regiões, enfatizando a intenção de "construção do território" por meio da arquitetura. Segundo Frampton, pensando sobre a integração da forma construída pelos homens à superfície da terra, construir o solo seria o ato primordial (1980). A fabricação do território é enfatizada como estratégia para estabelecimento de uma forma pública frente à nova natureza que viria à tona com a emergência das regiões urbanizadas. Tal via discursiva seria fundamental para algumas formulações teóricas e práticas na arquitetura brasileira.

\section{A noção de Território nas leituras da arquitetura}

Parece importante, tendo em vista o conteúdo dessas categorias, uma ressalva sobre o significado da noção de território para além da extensão física mas também, e principalmente, como conceito político que implica relações de poder. O desenho totalizante que organiza o território pode não ser uma forma de abrir-se como "espaço da aparência pública", mas significar a desterritorialização de outras formas de apropriação do espaço, sem garantir abertura à multiplicidade de relações diversas também como formas de territorialização. Sobre esse tipo de relação, o filósofo e psicanalista Felix Guattari faria uso de imagens como espaço liso e espaço estriado; 
8 A ideia de que a natureza (como um Outro) deve apenas ser dominada e tornar-se algo à semelhança daquilo que consideramos "humano" tem sido refutada pela antropologia contemporânea por algumas vias. Trabalhos de Bruno Latour e de Eduardo Viveiros de Castro fornecem um debate importante para o campo da arquitetura que faz uso de noções de "território", "geografia construída" e "construção da paisagem". Para além disso, a ideia de aversão àquilo que se considera "inumano" encontrou importante resistência na filosofia de Georges Bataille, em "O Erotismo" dentre outros estudos. Isso viria em contraponto ao positivismo da antropogeografia de Fiederich Hatzel, por exemplo, que serviria de base para o pensamento de Vittorio Gregotti ao pensar o Território da Arquitetura. o primeiro de fluxos desterritorializados e o segundo de sobreposição de fronteiras identitárias e multiplicidades em coexistência e conflito (GUATTARI, 1986). As relações territoriais, portanto, se constituem por camadas que vão além da demarcação do espaço e que podem ser reprimidas por ela: as formas de subjetivação, de circulação do desejo e de apropriações diversas e múltiplas. Guatarri, assim, insistiria na multiplicidade de territórios identitários em convivência. Parece haver um cruzamento, neste ponto, entre a necessidade de afirmação do "espaço de aparência pública", como espaço cívico marcado pela ação política, e o pensamento sobre os espaços de multiterritorialidade. A ideia de "construção do território", talvez possa ser pensada mais a partir da multiplicidade abarcada e menos pela via da forma totalizante que delimita com clareza a construção de "um" território, ou da ação humana que domina e da forma à natureza. Pois aquilo a ser considerado inumano, poderia ser um "outro" qualquer, compreendido como externo à nossa natureza construída. ${ }^{8}$

Diferente da necessidade de construir uma paisagem única, uma série de projetos megaestruturais foram pensados dentro de um contexto de contracultura com forte discurso sobre o nomadismo. No entanto, o instrumento que mediava essas experimentações era sempre a técnica em seu extremo, a tecnotopia, que viabilizaria uma condição nova também em termos de organização social. As estruturas projetadas para cidades nômades, em busca de superar a força da gravidade, resultavam em elementos ainda mais pesados e concretos. Parecia haver um conflito na forma de concretizar estes ideais por meio da construção. Como lembrado por Gorelik, seguindo Tafuri, há uma contradição em termos quando se fala em vanguarda arquitetônica, uma vez que a arquitetura é construtiva e não uma prática negativa (GORELIK, 2005). As experiências megaestruturais que buscavam superar o solo como condição, resultariam em grandes e pesadas estruturas nostálgicas de um futurismo tecnotópico.

Assim, a condição de atenção à topografia e à construção do chão, explorada por Frampton, busca o contrário. O desenho do chão público se pretende a base para uma abertura incondicional de relações sociais e políticas, de fluxos e usos flexíveis, sem que isso seja necessariamente representado por meio da construção. Os vazios e articulações espaciais fariam o papel de catalizadores das relações desejadas. Como pontuou Michel Foucault em entrevista para Paul Rabinow, não há espaços que gerem liberdade; "a liberdade é uma prática" (HAYS, 1998). Em direção parecida, Arendt quando expõe a ideia de "espaço de aparência", fundamental para Frampton, diz que "o poder tem um espantoso grau de independência de fatores materiais" e que "o único fator material indispensável para a geração de poder é a convivência entre os homens". Para o historiador, esta mesma passagem de Arendt revela a centralidade dos "espaços de aparência" aos quais recorre em sua defesa das Megaformas como construção cívica e topográfica do lugar na cidade contemporânea.

\section{Uma leitura da experiência brasileira}

Frente a este panorama conceitual, que trabalha ideias de espaço, lugar, forma, poder, ação política e caráter simbólico dos edifícios, os cruzamentos, ambiguidades e oposições na aproximação entre os conceitos de Megaestrutura e Megaforma parecem abrir um caminho possível de análise de aspectos da arquitetura brasileira. 
9 Noção de Friederich Ratzel utilizada por Frampton.

Figura 3: Estudo para a cidade do Rio de Janeiro - Le Corbusier Fonte: Le Corbusier. Precisões.
Marco fundamental, no Brasil, de um pensamento que mistura aspectos megaestruturais à condição de Megaforma e de construção da paisagem urbana por meio da arquitetura, é sem dúvida a passagem de Le Corbusier pelo país. Seus desenhos para São Paulo e para o Rio de Janeiro em 1929 marcam um raciocínio para o futuro das cidades que partia do desenho, que submetia a natureza e a paisagem ao "cálculo totalizante", para usar o viés de Tafuri na leitura de Gregotti. O enfrentamento de uma paisagem em grande parte disponível, natural, e em vias de ser urbanizada, é base para operações de projeto que teriam como prerrogativa a construção de uma "nova natureza", a saber, a construção de uma geografia humana ${ }^{9}$. A ideia de construção do território perpassaria desde este momento, passando pela construção de Brasília como incursão pelo interior do território nacional, até a arquitetura de Paulo Mendes da Rocha, traduzindo em sínteses formais um discurso sobre a América como nova civilização possível, a técnica como modo de existir dos homens sobre a natureza, buscando exemplos de Veneza a Kenzo Tange.

A abordagem de Le Corbusier ao pensar outro modo de habitar possível, como um olhar para a paisagem a ser construída no "novo continente", parece ter marcado fortemente a formação dos arquitetos brasileiros que começavam a atuar naquele momento. Experiências como o Pedregulho e o conjunto da Gávea, de Affonso Eduardo Reidy, certamente foram decorrentes desse precedente e gerariam casos exemplares da Megaforma de Frampton.

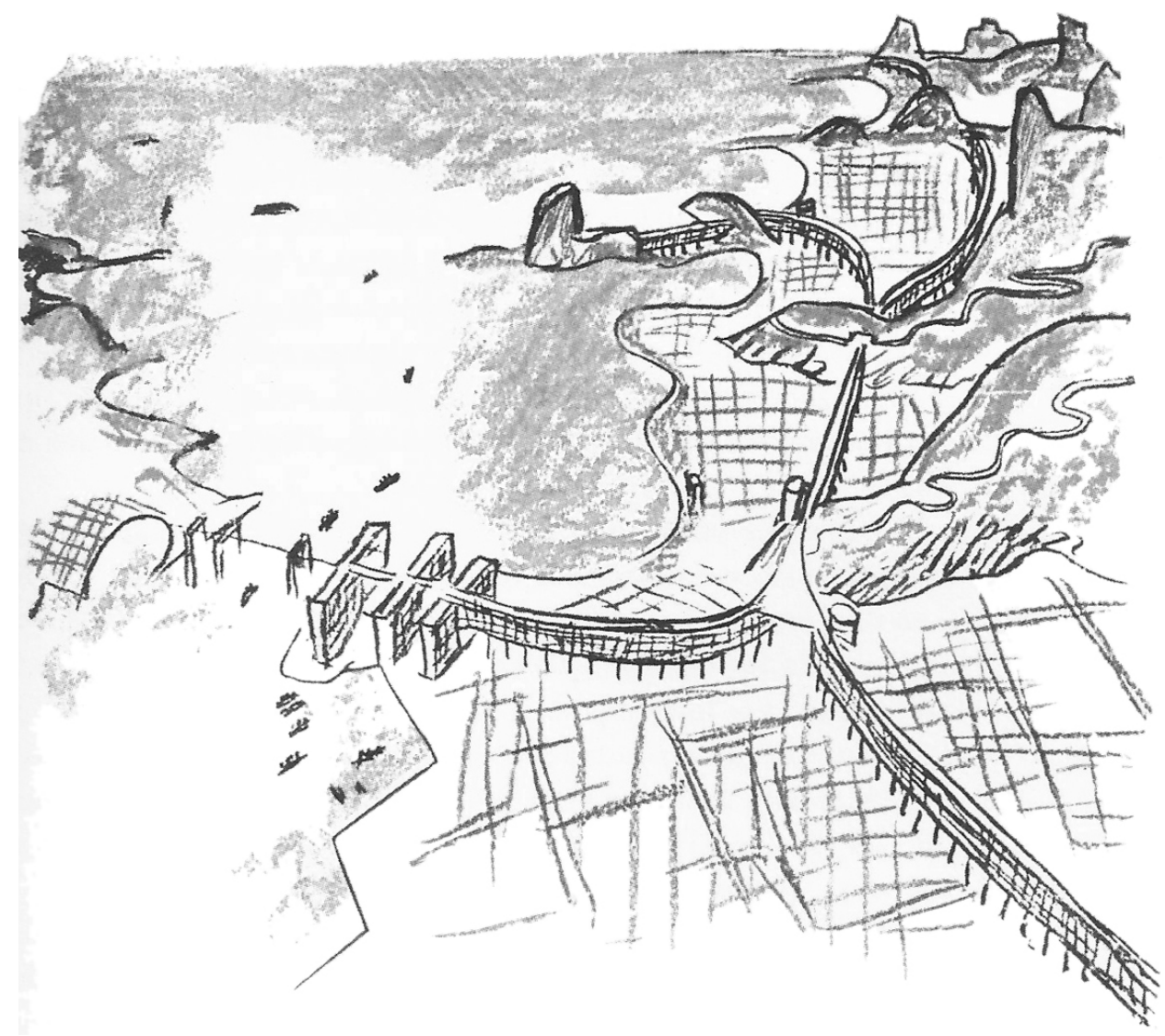



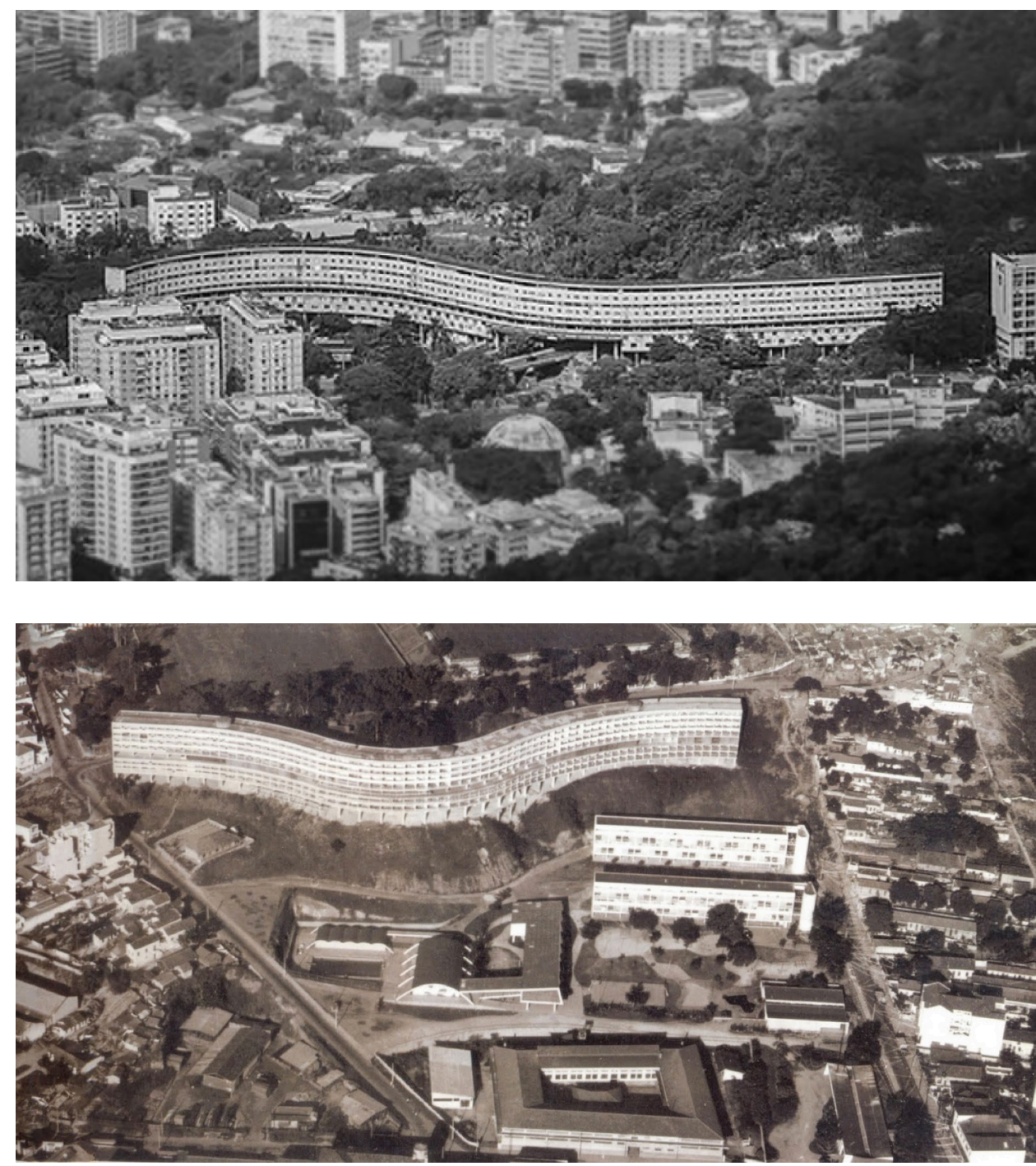

Figuras 4 e 5: Vista aérea do conjunto nos anos 1950. Fonte: BONDUKI, Nabil. KOURY, Ana Paula. Pioneiros da Habitação Social no Brasil. Vol. 03: Acervo do Departamento de Habitação Popular da Prefeitura do Distrito Federal.

10 Tema trabalhado por FRANDLICH, Rafael Urano Rastros do Horizonte. In. CONTRAVENTO n.6. Abril 2015. São Paulo.
Se os conjuntos de disposição horizontal extensa, que acompanhavam a topografia e se inseriam na paisagem delimitando a ocupação daquele "território", foram importantes enquanto desdobramentos do pensamento corbusiano, outro viés que teria forte relação com a categoria de Megaforma pôde ser experimentado em Brasília. Uma série de edifícios de caráter simbólico marcante teriam suas principais operações de projeto feitas a partir de um desenho da relação com o chão, com a topografia, da integração espacial entre interno e externo, da articulação de níveis, e, no geral, desenvolvendo-se em disposições horizontais. Em Brasília haveria um diálogo constante com a linha do horizonte, e o problema do horizonte e da terra seria central na elaboração formal desses projetos. ${ }^{10} \mathrm{~A}$ tensão entre cobertura e pontos de apoio seria sintomática e representativa da realidade brasileira, segundo Sophia da Silva Telles (TELLES, 1998). Esta segunda via de desenvolvimento da Megaforma na arquitetura brasileira se dá mais por aspectos estéticos e soluções de disposição espacial, que propriamente pela dimensão e pelo desenho da paisagem em sua extensão. O desenho da paisagem aqui se dá mais pela topografia e pela forte síntese formal presente nesses edifícios, em 
11 ver CORULLON, Martin Gonzalo A plataforma rodoviária de Brasília: infraestrutura, arquitetura e urbanidade. São Paulo, 2013.

Figura 6: Rodoviária de Brasília. Fonte: Archidaily / foto: Mario Fontenelle. diálogo com a paisagem do cerrado e com a paisagem cultural moderna simbolizada, em construção. Por outro lado, em Brasília, a rodoviária como edificação que marca o cruzamento de eixos na cidade e se constrói a partir de uma sobreposição de níveis mantendo-se radicalmente horizontal e topográfica, é exemplo perfeito de uma construção do chão, sendo uma Megaforma de construção de infraestruturas e da paisagem ${ }^{11}$.

Contemporânea a este desenvolvimento da arquitetura carioca, principalmente, que se dava em Brasília, a arquitetura paulista vivia momento rico e de importantes consolidações a partir do fim dos anos 1950. Principalmente a partir de projetos de Villanova Artigas, uma forma de pensar a arquitetura com destaque para seu aspecto construtivo, para a tensão estrutural e para a racionalidade da técnica, como elementos centrais do desenho, seria difundida em um contexto de busca do desenvolvimento industrial. Em um momento de grande investimento público, essa arquitetura teria algumas de suas primeiras concretizações importantes principalmente na construção de escolas e na universidade. Os projetos construídos neste momento deram seguimento às soluções estudadas por Afonso Eduardo Reidy no Museu de Arte Moderna do Rio de Janeiro e na escola Brasil-Paraguai, referencias inaugurais

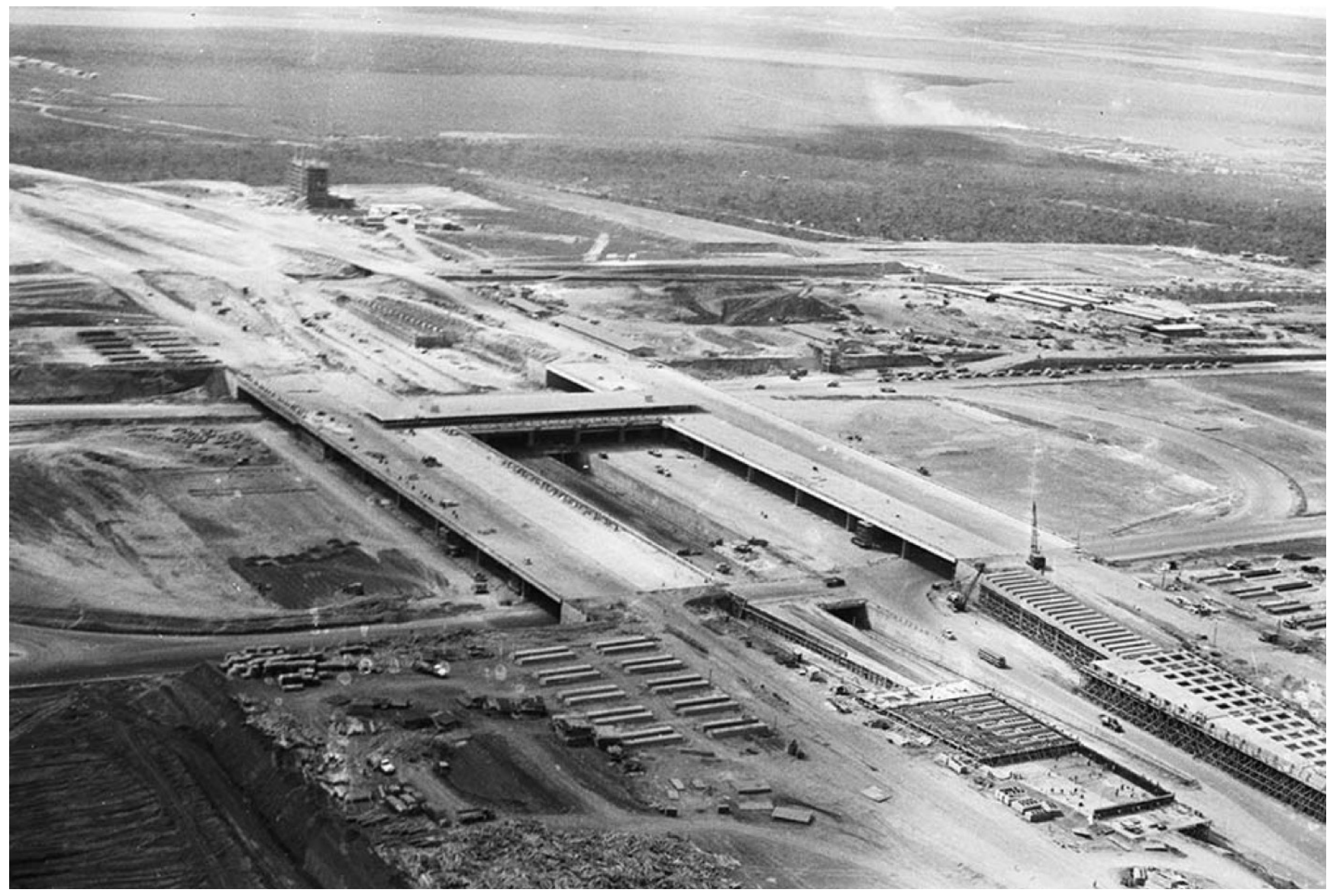

risco. 16_1 
no uso do concreto armado aparente como recurso à expressividade do material. Para Artigas, o trabalho da construção estaria exposto nas marcas da fôrma de concreto e a tensão estrutural dada pelo desenho evidenciava a estática. Desse modo, buscava-se um caminho diverso do de Oscar Niemeyer, ainda que em consonância com depoimentos do arquiteto carioca à época da construção de Brasília, rumo a uma arquitetura racional (XAVIER, 2003). A expressividade da estrutura e seu peso no desenho de volumetrias e espaços parece estar em consonância com o debate contemporâneo da época, no qual as megaestruturas tinham papel de destaque. Guilherme Wisnik procura definir a arquitetura paulista como uma tomada de caminho radicalmente diversa daquela feita pela arquitetura carioca, principalmente por seu caráter megaestrural e por seu papel de construção do território (2003). A construção do território, no caso, se daria por aspectos mais metafóricos e principalmente topográficos. A natureza seria tragada para dentro do edifício, segundo Wisnik. O grande volume de concreto teria poucas aberturas para o exterior, ao mesmo tempo que total fluidez no nível do chão, tornando a articulação dos espaços internos e externos mais natural que nas experiências anteriores. A centralidade do papel da técnica confere também essa força ao movimento de construção de uma nova geografia, de um caráter topográfico. Wisnik lembra, no entanto, que a arquitetura paulista criaria laboratórios de uma sociabilidade nova, dentro dos limites da casa como experimento. Para além da construção de escolas, o desenho da casa buscou urbanizar a vida privada, num movimento de educação da burguesia (ARANTES, 2002). Algo muito diferente do que ocorreu com a arquitetura carioca, que seria parte constantemente da construção de espaços públicos, exercendo muitas vezes o papel de monumento público e sendo inserida necessariamente como elemento construtivo da sociabilidade urbana pública (WISNIK, 2003). A experimentação espacial, no entanto, mais típica à categoria da Megaforma, parece ser um traço fundamental da arquitetura desenvolvida em São Paulo entre os anos 1950 e 1960, de modo que fora associada muito mais vezes à ideia de construção topográfica e até mesmo de uma arquitetura de caráter público, chegando a ser lida dessa maneira pelo próprio Frampton (1980).

Vale mencionar ainda um conjunto de experiências de projeto fundamental neste debate: o campi da Universidade de Brasília, contemporâneo ao campi da Universidade de São Paulo como momento importante de desdobramentos do arquitetura paulista, é demonstração potente de como tanto o "brutalismo" quanto o caráter megaestrutural não eram bem especificidades paulistanas. Em Brasília, na construção da universidade, os aspectos construtivos ligados à pré-fabricação e ao caráter industrial e racionalizado das obras ganhavam força. Entre São Paulo e Brasília, pode-se notar um diálogo neste momento como, por exemplo, na atuação de Pedro Paulo de Melo Saravia no Ceplan, órgão de planejamento da UnB, sucedendo João Figueiras Lima. Na UnB um edifício como o Refeitório Central representa a força do desenho da estrutura como expressividade, ao mesmo tempo que o edifício para o Centro de Ciências partiria das tecnologias de construção pré-fabricada, criando um edifício como corpo vivo que pudesse receber novos módulos de sua estrutura, organizada entre ritmo de repetição e disposta em curva. Ali se realizava um experimento de construção tão voltado à indústria e ao desenvolvimentismo brasileiro da época, quanto atento às ideias de flexibilidade por meio de módulos acopláveis em megaestruturas, assim como estava em total acordo com a paisagem construída de Gregotti. 
Figura 7: Instituto Central de Ciências - Universidade de Brasília. Fonte: Revista Acrópole, n.369.

12 Neste aspecto, a leitura de Tafuri sobre o projeto de Argel de Le Corbusier pode servir como referência, abordando o mesmo tema sobre a célula e o corpo total, como relação de flexibilidade e rigidez. TAFURI, Manfredo. Architecture and Utopia. The MIT Press. 1976.

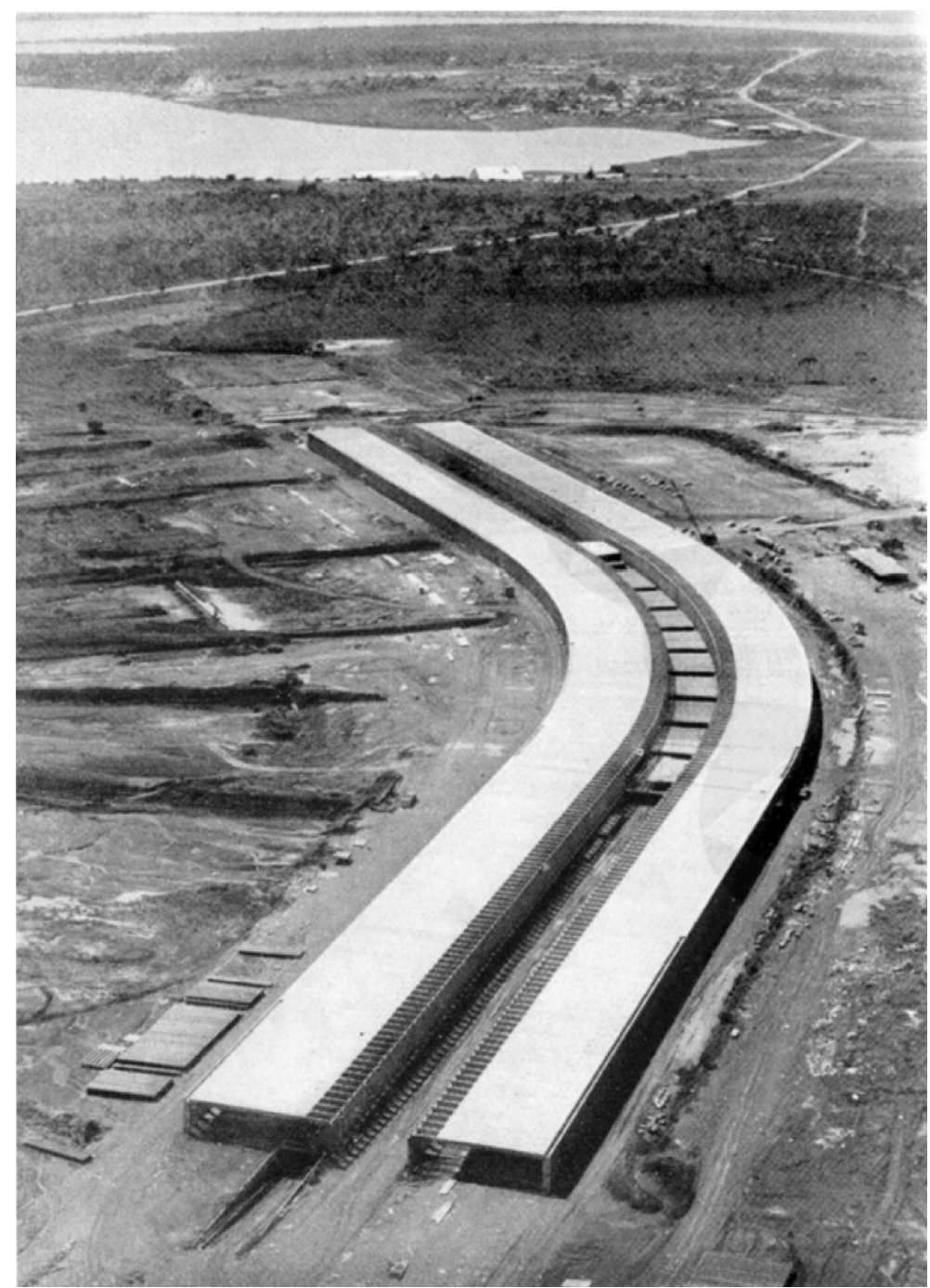

Também em deslizamento entre as noções de Megaforma e Megaestrutura, podemos citar o projeto de João Figueiras Lima, Lelé, para o Centro Administrativo de Salvador. O projeto é reconhecido na historiografia da arquitetura brasileira por seu caráter modular e, assim como no Centro de Ciências de Niemeyer, configurando um grande volume curvo a partir de células rígidas de estrutura perimetral ${ }^{12}$.

A arquitetura brasileira atuaria dentro do debate megaestrutural também com experimentações em menor escala, elaborando tais problemas por meio de sínteses. Como dito anteriormente, uma abordagem importante para o tema do desenho do chão, na arquitetura brasileira foi desenvolvida por Sophia Telles, ao olhar para a arquitetura de Niemeyer como representativa da tensão existente no ato de tocar o solo. Para ela, Paulo Mendes da Rocha inverteria essa relação ao movimentar o solo, o terreno, em direção à cobertura, como fez no Pavilhão de Osaka em 1969. Ali e em alguns projetos posteriores, como no Museu de Escultura, em São Paulo, o arquiteto elaborava sínteses fortes dessa construção topográfica, marcando diferentes níveis e espaços sob uma só cobertura. Se, como para Wisnik, tal cobertura constituía um 

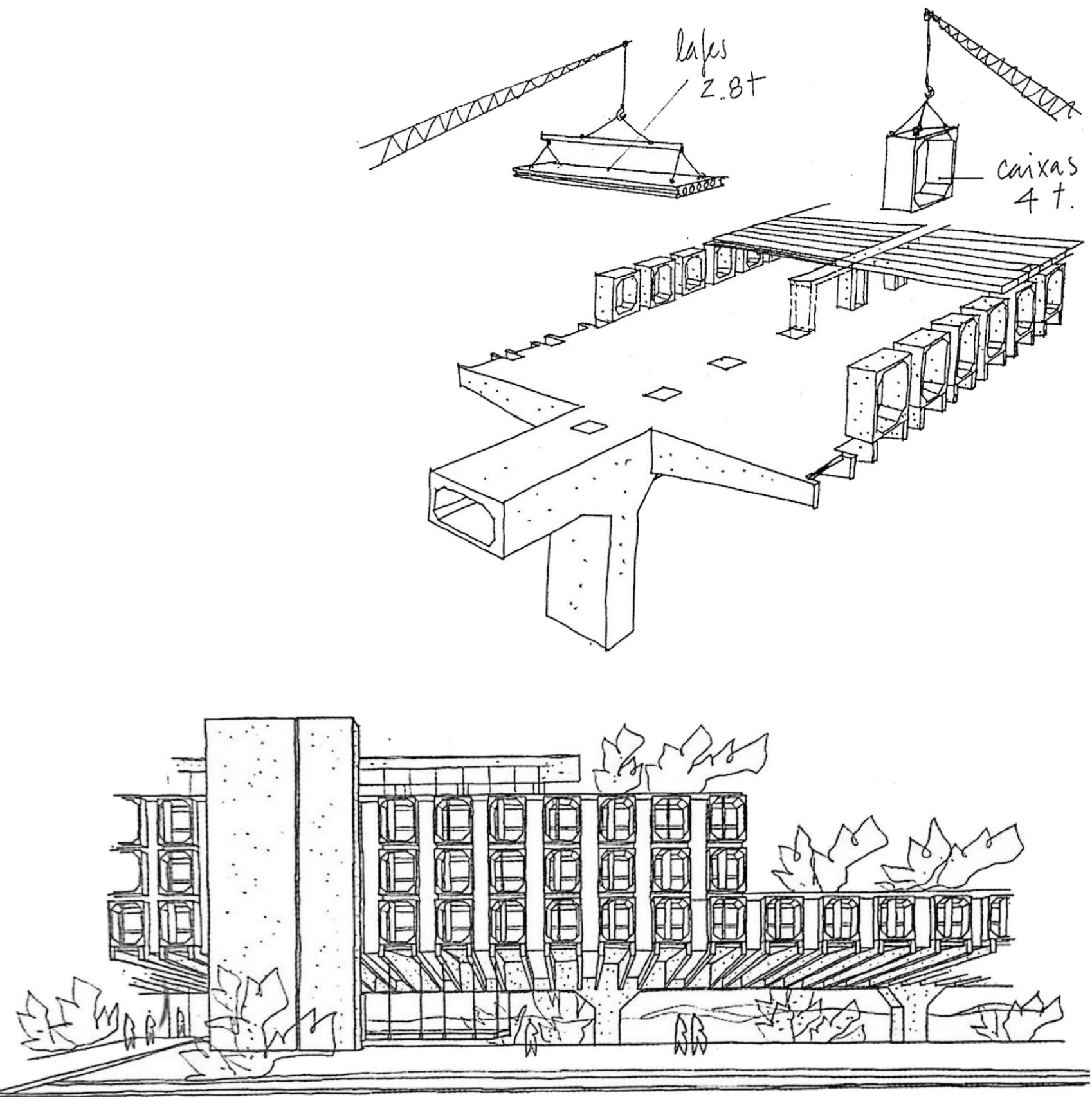

Figuras 8 e 9: Centro Administrativo de Salvador, BA - João Filgueiras Lima - 1974. Fonte: Archdaily / João Filgueiras Lima.

13 ver Revista Acrópole Número 361; Sobre o concurso do Pavilhão de Osaka, ver COSTA, Juliana Braga. Ver não é só ver: dois ensaios a partir de Flávio Motta. Dissertação de mestrado. FAUUSP. São Paulo. 2010 abrigo sob sua sombra e, em muitos casos, tragava para os espaços internos os jardins e espaços livres, isso implicava, de certa forma, o mesmo aspecto totalizante das Megaestruturas. Tal movimento de guardar toda a diversidade de volumes e relações espaciais sob uma única cobertura configurava, de fato, um protótipo de Megaestrura em escala menor. É interessante, por exemplo, que o Pavilhão de Osaka tenha sido um concurso em 1969, quando grande parte dos projetos apresentados e publicados em periódicos especializados dialogavam com a tendência megaestrutural ${ }^{13}$. Os projetos que concorriam para o pavilhão brasileiro eram, em sua maioria, muito bem inseridos dentro dos procedimentos de projeto típicos das Megaestruturas. 
14 Para o concuso do Clube XV ver Revista Acrópole Número 366 e DEDECCA, Paula. Sociabilidade, crítica e posição. $O$ meio arquitetônico, as revistas especializadas e o debate do moderno em São Paulo (19451965). Dissertação de mestrado. São Paulo: FAUUSP, 2012

Figura 10: Clube XV, Santos, SP - Pedro Paulo de Melo Saraiva, 1963. Fonte: Revista Acrópole.
É interessante que, nesse caso, o Pavilhão de Osaka apareça em debates de Frampton sobre a Megaforma. Certamente isso se dá por sua característica marcante de construção da topografia artificial que sustenta a cobertura, e os vazios programáticos gerados por tais elementos. O caso de Paulo Mendes da Rocha é talvez o mais claramente marcado pelo problema da dominação da natureza pelo homem. Como trabalhado pelo historiador Daniele Pisani (2013), o arquiteto tem em Veneza uma de suas mais importantes referencias pois compreende sua ocupação como genuína construção do território. Seu projeto para a Fundação Getúlio Vargas é exemplo da maneira como uma nova cota é definida por uma geografia humana, seguindo rigorosamente o caminho de Gregotti. Para além do aspecto da construção topográfica, valorizado por Frampton, vale lembrar projetos do arquiteto como o MuBE e o projeto para a Praça do Patriarca, também em São Paulo, que configuram coberturas abrigando espaços livres públicos, indo ao encontro daquilo que desenvolve Frampton ao insistir na categoria de "espaços da aparência pública" criados pela "forma cívica". É assim que tais projetos são apresentados pelo historiador na conclusão da quarta edição de sua história crítica (FRAMPTON, 2010).

Um projeto que desperta interesse enquanto Megaforma é o edifício para o Clube $X V$, em Santos, da autoria de Pedro Paulo de Melo Saraiva. Este projeto marca a horizontalidade das vigas longitudinais do edifício, estendendo-as para fora do espaço interno, avançando sobre a praça pública e marcando tanto a expressividade da estrutura quanto o caráter horizontal e aberto desejado para aquele espaço. Em croqui de inserção do projeto, Saraiva demonstra o aspecto horizontal notável diante do entorno adensado e verticalizado da orla. Este desenho marca com força o caráter de praça que o edifício busca construir ${ }^{14}$. A força do concreto armado e de seu desenho, talvez superdimensionado, é típica daquele momento da produção paulista, trabalhando procedimentos de desenho da estrutura por meio do tensionamento nos pontos de apoio que, de certa forma, dialogam com as Megaestruturas por tratar de modo tão enfático a proporção da estrutura com relação ao todo e aos espaços gerados pelo edifício.

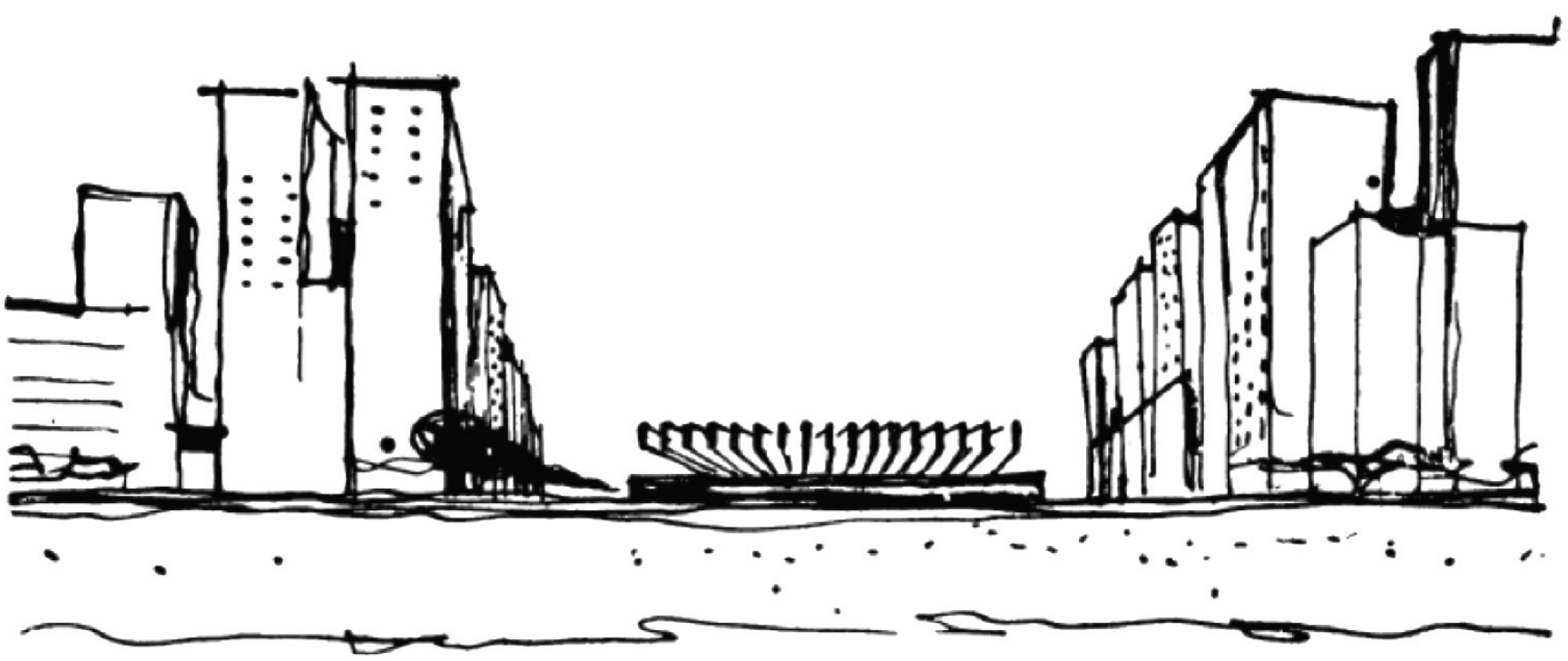



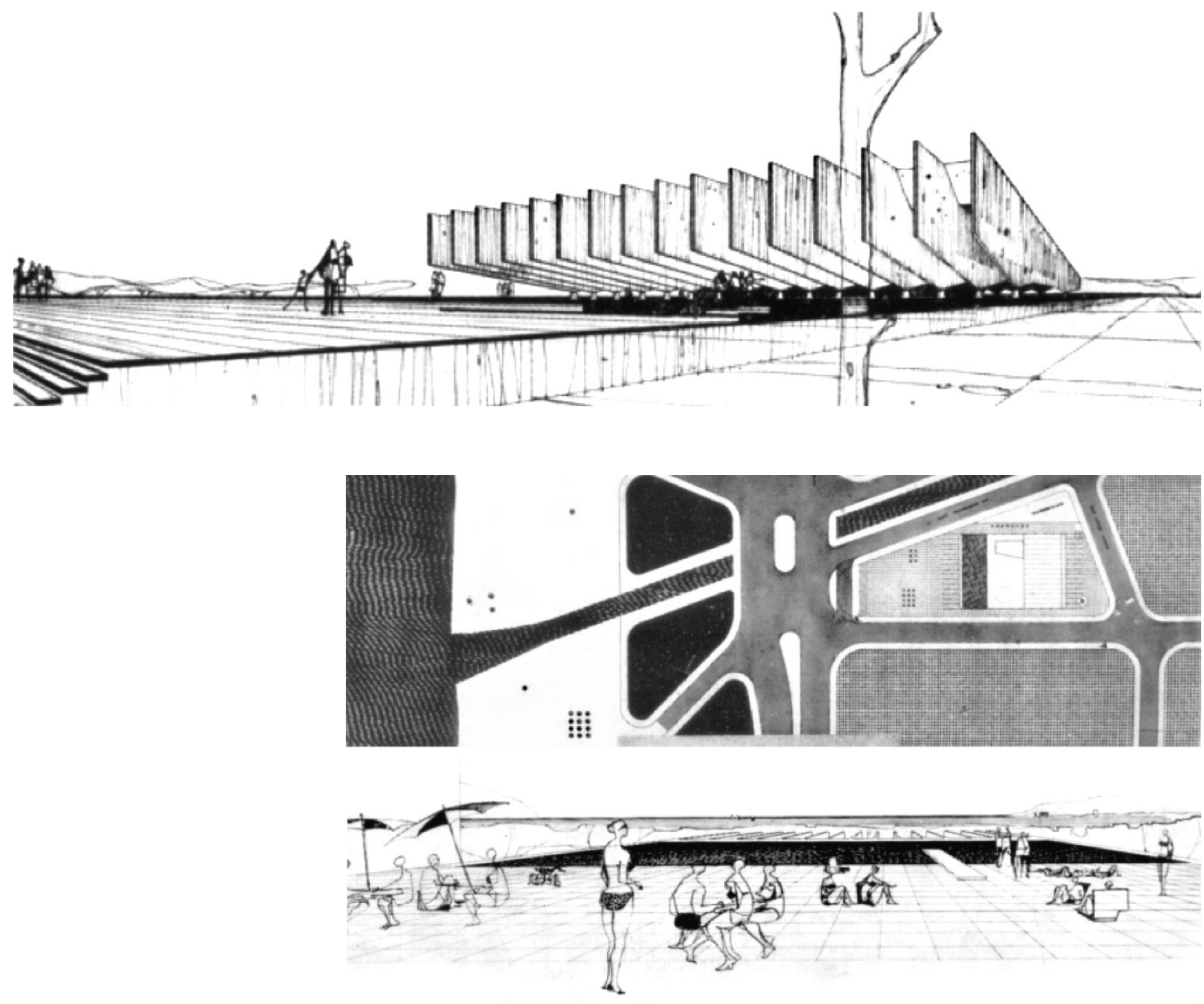

Figura 11: Clube XV, Santos, SP - Pedro Paulo de Melo Saraiva 1963. Fonte: Revista Acrópole.
Também em Santos, um projeto de Décio Tozzi que suscita diálogos entre a Megaforma e a Megaestrutura é o projeto para a Escola Técnica de Comércio. Ali, a expressividade do concreto salta aos olhos novamente. Não por meio da tensão nos pontos de apoio ou pelo desenho das forças estáticas, mas pelo desenho da cobertura do edifício com aberturas de iluminação zenital. O projeto guarda aspectos de Megaestrutura principalmente por esta quantidade de elementos desenhados com o mesmo peso na hierarquia de materiais; todo em concreto armado, é visto por fora como um volume de forte aspecto industrial e infraestrutural. Os espaços internos, no entanto, apresentam uma rica articulação entre vazios programáticos, entre entradas de luz e volumes soltos dispostos sob a grande cobertura. Nessa riqueza espacial, talvez o caráter de Megaforma esboce aparecer, mas também na implantação do edifício desejada por Tozzi, visível em seus croquis para o projeto. É possível notar como o projeto fazia parte de um conjunto imaginado, como um plano local, com outros edifícios ligados por 
Figuras 12 e 13: Escola Técnica de Comércio - Santos - Décio Tozzi, 1963. Fonte: Cadernos Brasileiros de Arquitetura. meio de passarelas sobre a rua. Assim, um embasamento comum também conecta os edifícios, e a forma horizontal da Escola Técnica parece estar diretamente associada a esta convivência com outros programas que conformam a malha urbana daquela área. Pela foto do edifício construído, em vista do mesmo ângulo que o croqui, pode-se notar como aquela construção de um território novo, conectando lugares por meio de uma topografia nova construída, não havia sido efetivada e parece, ao contrário, desterritorializar uma ocupação existente naquele local e que ainda conflita com o edifício dividindo um mesmo muro. A construção dessa paisagem imaginada por Tozzi é interrompida por pequenas casas da cidade existente, criando uma forte imagem de síntese de relações territoriais enquanto relações de poder.
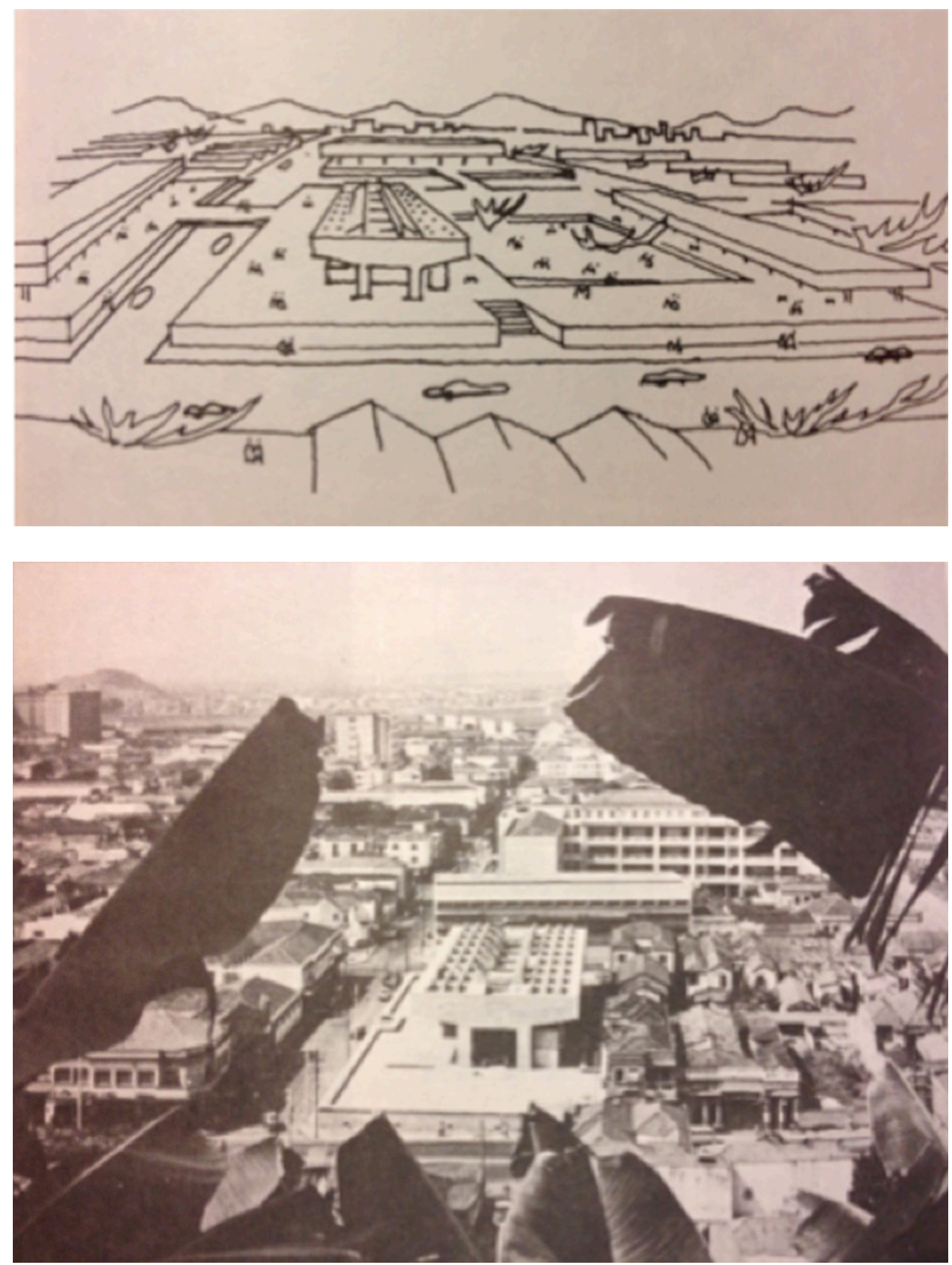


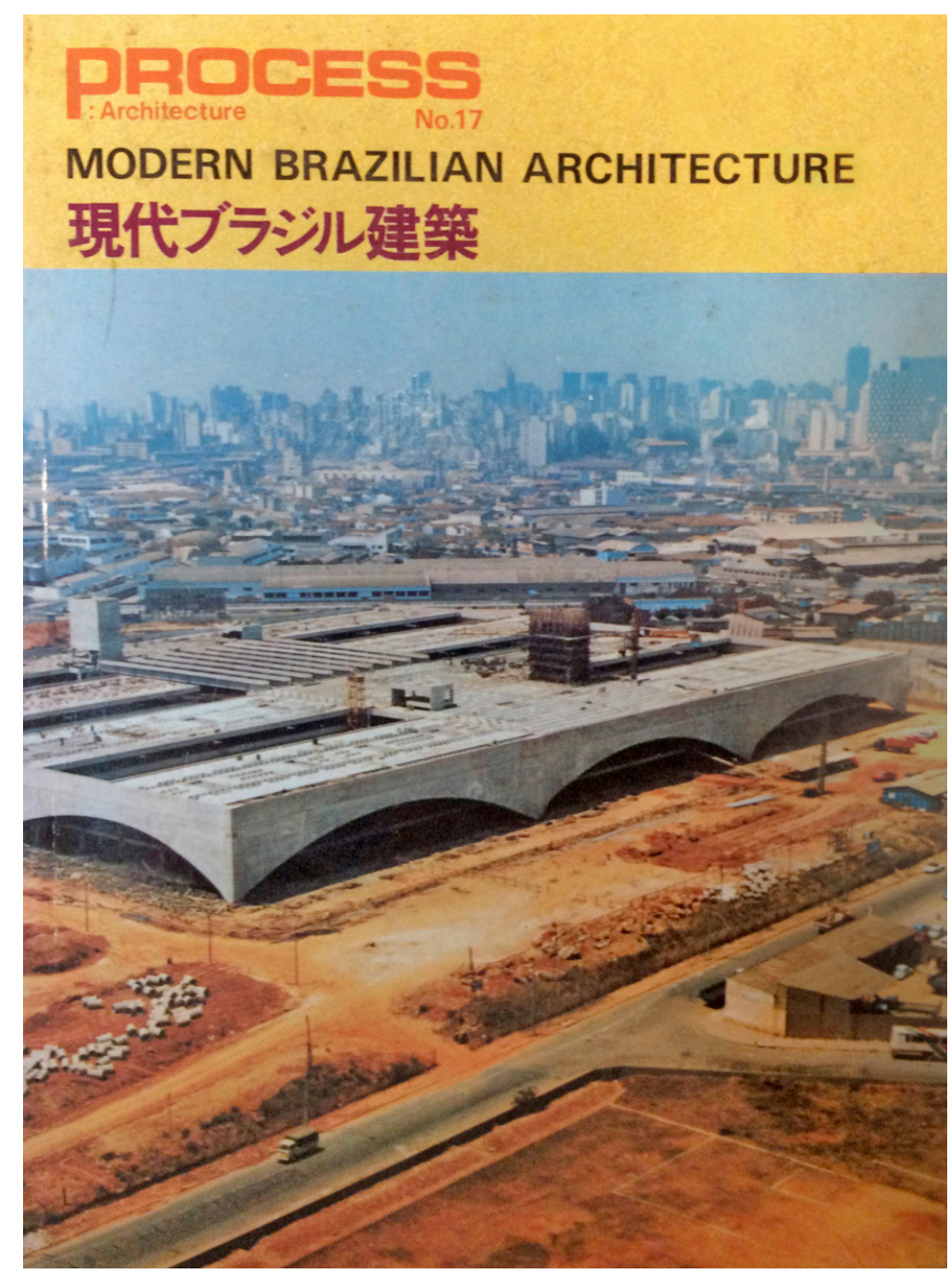

Figura 14: Hospital Escola Júlio de Mesquita Filho - Santa Casa - São Paulo, SP - Fábio Penteado (capa da revista japonesa Process, n.17, 1980).
Outro exemplo de dificuldades na inserção urbana pode ser visto no projeto de Fábio Penteado e Teru Tamaki para o Hospital Escola da Santa Casa, feito em 1963, junto ao eixo de expansão metropolitana do rio Tietê. Ali, como em grande parte da arquitetura moderna brasileira, o edifício fora pensado para uma cidade futura que estava em vias de se concretizar. Aquele eixo receberia os projetos para o Anhembi, obras viárias de grande porte, e conectava regiões da periferia ao centro da cidade. $\mathrm{O}$ programa de um Hospital Escola é de natureza eminentemente pública, uma vez que atende público externo a todo momento, e que funciona também como universidade. Este projeto sofreria, no entanto, de um fator contingente quando a instituição que o concretizaria não possuía mais verba para arcar com a conclusão do edifício, de sua ocupação como hospital e acabou por vender ao governo do Estado a estrutura já em construção para que a ela fosse dado outro uso. O edifício viria a se tornar Fórum Criminal, mantendo um caráter público de circulação, mas de uma natureza muito diferente. De todo modo, um problema central na concretização do edifício em questão seria sua inserção urbana comprometida por um entorno que não acompanhou as expectativas de urbanização da época. A região continuava majoritariamente como um parque industrial, e o resultado das obras de infraestrutura seria o de tornar aquela 
região refém das qualidades típicas de áreas lindeiras às vias expressas. A paisagem urbana ali quase não teria marcas de vida pedestre, embora o edifício se projetasse como uma Megaestrutura aberta, horizontal e topográfica. Exemplos como este nos levam de volta à afirmação de Foucault sobre a liberdade como prática, ou à de Arendt sobre a materialidade da convivência entre os homens.

Um dos projetos brasileiros que talvez melhor dialogue com a noção de Frampton de Megaforma foge um pouco à linguagem que está mais diretamente associada às leituras do autor que se voltaram ao Brasil: o Centro Cultural São Paulo, projetado por Eurico Prado e Luiz Telles.

Sem os mesmos atributos típicos da lógica espacial e estrutural da arquitetura desenvolvida em São Paulo a partir dos anos 1950, nem o mesmo tratamento tectônico, este projeto encarna fortemente aspectos levantados por Frampton. A integração do edifício à topografia, tratando-se de uma encosta de vale; a integração urbana, com diversos acessos e ligação direta com o transporte público; a abertura à cidade a partir de seus vazios internos; a articulação de níveis entre grandes vazios, de áreas expositivas, áreas de estudo, biblioteca e praças abertas, até cobertura como parque. Os vazios de programa se abrem à apropriação dos espaços com grupos de dança e jogos.

O caso brasileiro, visto a partir de alguns exemplos específicos, mostra interessantes conflitos e potenciais da categoria trabalhada por Kenneth Frampton. Voltando aos casos estudados pelo autor, Frampton vê, por exemplo, no projeto de L'illa de Rafael Moneo e Manuel de Solà Morales, em Barcelona, um caráter horizontal marcante do edifício e sua inserção como marco urbano com acesso franco por pontos diferentes conectando a malha urbana. Para o autor, este projeto é um exemplo paradigmático da Megaestrutura. No entanto, o uso do edifício, apesar de intenso e marcado por fluxos de caráter urbano essencialmente público, é majoritariamente comercial funcionando mais como um shopping-center que como "forma cívica" ou lugar da "ação política", no sentido arendtiano. Outro caso conflituoso, já mencionado aqui, é o Baker Dormitory, de Alvar Aalto, que se configura horizontalmente e por meio de uma implantação em curvas que lembra os projetos de Le Corbusier como construção da paisagem. No entanto, ali também não se nota a abertura de um espaço cívico de urbanidade pujante, de integração de espaços internos e externos ou de convivência pública. O caráter topográfico, neste edifício, parece estar mais na leitura da tectônica feita pelo autor para o desenho de escadarias do edifício marcadas na fachada ou pelas curvas da planta - que em outros casos dialogam com aspectos geográficose - que propriamente na construção de disposições espaciais a partir dos níveis, dos vazios criados ou da implantação.

Deste modo, o interesse de Frampton pela arquitetura brasileira é compreensível uma vez que elementos fundamentais das categorias valorizadas pelo autor são encontradas em diversos edifícios produzidos pelas arquiteturas moderna e contemporânea no país. Para ficar nos cânones, as fomas de ocupação constantes de marcos urbanos como o vão livre do MASP, como a marquise do Parque do Ibirapuera, ou no Rio de Janeiro as diversas formas de apropriação pública dos edifícios como MAM, se configuram como "espaços de aparência pública" principalmente pelo uso que lhes é dado ao longo da história. Do carnaval às manifestações políticas, estes marcos urbanos edificados se abrem à permeabilidade da vida pública. 
15 Este debate está muito bem retratado no livro organizado por Stan Allen na Universidade de Princeton. ALLEN, Stan. \& McQUADE, Marc. orgs. Landform Building: Architectures new terrain. Princiton University School of Architecture. Lars Müller Publishers. 2009.
A Megaforma dialoga diretamente com abordagens dadas recentemente à intersecção entre projeto de edifícios, desenho urbano e desenho da paisagem. É comum que estes interesses levem a uma busca por analogias entre forma arquitetônica e forma geológica, formas naturais, forma topográfica. A ideia de topografia de Frampton, voltada a um viés como aquele dado por Gregotti na construção do solo e da "geografia humana", parece se perder em meio a uma estetização dos conceitos e do olhar para a construção da paisagem. Isso pode ser notado em narrativas sobre a paisagem na arquitetura que privilegiam o olhar para projetos como o edifício The Mountain, de Bjarke Ingels, que organiza seu programa de modo convencional mas o reveste em uma volumetria de referência metafórica à paisagem, por meio da forma "montanha" 15 . A atenção para o desenho da "geografia humana" não está presente nessa abordagem formal e metafórica da geografia física. Neste caso, as imagens presentes em uma formulação teórica que buscava a construção do "espaço cívico" em sua potência máxima, são apropriadas com a finalidade de potencializar agora a "renda da forma", para usar a expressão de Pedro Arantes (2012). A presença de imagens fortes e sínteses discursivas, como no caso de Paulo Mendes da Rocha no Pavilhão de Osaka e no MuBE - e as leituras da historiografia consagradas para ambos - também trabalham em uma linha tênue frente à estetização dos significados que guardam em potencial. Os procedimentos de formalização, de desenho da estrutura e do espaço, presentes em projetos canônicos da arquitetura feita em São Paulo nos anos 1960, por exemplo, foram - em muitos casos - repetidos exaustivamente e levados a um processo de didatização forçada, como descreve Sérgio Ferro (1967), sem mais correspondência com as expectativas sociais que animavam tais soluções, devido ao contexto político e produtivo.

Décadas atrás, no caso das Megaestruturas, ocorria algo parecido que Tafuri descrevia como um movimento de abandono das questões de reconstrução da cidade de fato, para uma reconstrução do universo, por meio de imagens. Nesse sentido, a busca de um futurismo estético acabava por elevar o desconhecido à condição de mito (1986). No debate atual sobre a arquitetura da paisagem e a construção do "território", é urgente a atenção para as formas de territorialidade que são proporcionadas de fato pelos projetos, menos entre referências metafóricas, como a da construção "do" território enquanto poder especializado, e mais entre espaços abertos à apropriação, à criação de lugares, aos "espaços de aparência pública" e à multiterritorialidade.

\section{Referências bibiográficas}

ALLEN, Stan. \& MCQUADE, Marc. orgs. Landform Building: Architectures new terrain. Princiton University School of Architecture. Lars Müller Publishers. 2009. ANDREOLI, Elisabetta; FORTY, Adrian (org.). Arquitetura moderna brasileira. New York: Phaidon, 2004.

ARANTES, Pedro Fiori. Arquitetura Nova. Sérgio Ferro, Flávio Império e Rodrigo Lefevre, de Artigas aos mutirões. São Paulo. Editora 34. 2002

ARANTES, Pedro. Arquitetura na era digital financeira: desenho, canteiro e renda da forma. Editora 34. 2012.

ARTIGAS, Rosa. Org. Paulo Mendes da Rocha. CosacNaify. 2006.

AUGÉ, Marc. Não Lugares. Editora Papirus. 2007. 
BANHAM, Reyner. Megastructure. Urban futures of the recent past. Themes and Hudson. London. 1976.

Teoria e projeto na primeira era da máquina. São Paulo: Editora Perspectiva, 1975. The new brutalism: ethic or aesthetic? London: The Architectural Press, 1966.

BASTOS, Maria Alice Junqueira; ZEIN, Ruth Verde. Brasil: arquiteturas após 1950. São Paulo: Perspectiva, 2010.

COSTA, Juliana Braga. Ver não é só ver: dois ensaios a partir de Flávio Motta. Dissertação de mestrado. FAUUSP. São Paulo. 2010.

DEDECCA, Paula. Sociabilidade, crítica e posição. O meio arquitetônico, as revistas especializadas e o debate do moderno em São Paulo (1945-1965). Dissertação de mestrado. São Paulo: FAUUSP, 2012.

"A ideia de uma identidade paulista na historiografia de arquitetura brasileira". Revista Pós, n. 32, São Paulo, dezembro, 2012, p. 90-101.

DELEUZE, Gilles. Conversações. Editora 34. São Paulo. 1992.

ESPALLARGAS Gimenez, Luis. Pedro Paulo de Melo Saraiva: arquiteto. São Paulo. Romano Guerra. 2016.

FERRO, Sérgio. Arquitetura e trabalho livre. São Paulo: Cosac \& Naify, 2006.

FRAMPTON, Kenneth. Labour, Work and Architecture. Collected Essays on Architecture and Design. Phaidon Press. 2002.

"Industrialization and the Crisis in Architecture", in HAYS, Michael (ed.). Oppositions Reader. Princeton: Princeton Architectural Press, 1998, pp. 39-64.

. Modern Architecture, a critical history. Themes \& Hudson. World of Art. London. 2010.

. Megaform as urban landscape. In. ALLEN, Stan. And McQUADE, Marc. orgs. Landform Building: Architectures new terrain. Princiton University School of Architecture. Lars Müller Publishers. 2008. (pp. 238-249).

Studies in tectonic culture. The MIT Press. London. 1995.

Entrevista, por José Lira. Revitsa Desígnio. 11/12. Mar.2011.

FLORENCE, Luis Ricardo A. Mecanismo e Paisagem. Reyner Banham e a América. Dissertação de mestrado FAUUSP. 2014.

FOUCAULT, Michel. Microfísica do poder. Graal. São Paulo. 2013.

GORELIK, Adrián. Das vanguardas a Brasilia: Cultura Urbana e Arquitetura na América Latina. Belo Horizonte: Editora da UFMG, 2005.

GREGOTTI, Vittorio. Território da Arquitetura. Perspectiva. São Paulo. 2010.

GUATTARI, Félix. Espaço e Poder. Espaço\&Debates. n.16. São Paulo 1986.

GUERRA, Abílio (org.). Textos fundamentais sobre história da arquitetura moderna brasileira. 2 vols. São Paulo: Romano Guerra, 2010.

HAESBAERT, Rogério. O mito da desterritorialização. Bertrand Brasil. Rio de Janeiro. 2004. Territórios alternativos. Editora Contextos. Rio de Janeiro.

HAYS, Michael. Org. Architecture Theory since 1968. The MIT Press.1998.

LIRA, José Tavares Correia de. O visível e o invisível na arquitetura brasileira. DBA. São Paulo. 2017. 
MEDRANO, Leandro Silva; RECAMÁN, Luiz. Vilanova Artigas: Habitação e Cidade na modernização brasileira. Campinas, SP. Editora da Unicamp. 2013.

MOTTA, Flávio. Desenho e emancipação. Originalmente publicado em Correio Braziliense. 1967.

NESBITT, Kate. Org. Uma Nova Agenda para a Arquitetura. CosacNaify. São Paulo.

PENTEADO, Fábio. Ensaios de arquitetura. São Paulo: Empresa das Artes, 1998.

PIANCA, Guilherme. Le Corbusier and São Paulo - 1929: Architecture and Landscape. Le Corbusier 50 years Later. International Congress. Valencia. 2015.

PISANI, Daniele. Venezia as a model, the case o Paulo Mendes da Rocha. In. HAULuP. Venezia Arsenale. Edited by Margherita Varone. IAUV.

Paulo Mendes da Rocha. Obra completa. Editora Gustavo Gili.

PRÓSPERO, Victor. P. Territórios no discurso arquitetônico. Trabalho Final de Graduação. FAUUSP. 2014.

SANTOS, Milton. Natureza do Espaço. Edusp. São Paulo. 2012.

SAQUET, M. e SPOSITO, E. Orgs. Territórios e territorialidades: teorias, processos e conflitos. São Paulo/Presidente Prudente: Expressão Popular, 2009.

SEGAWA, Hugo. Arquiteturas no Brasil 1900-1990. São Paulo: Edusp, 1998.

TAFURI, Manfredo. The Sphere and the Labirinth. The MIT Press. 1992. Architecture and Utopia. The MIT Press. 1976.

TAFURI, Manfredo \& DAL CO, Francesco. Modern Architecture. New York. Rizzoli. 1986.

TELLES, Sophia da Silva. Arquitetura Moderna no Brasil: O desenho da superfície. FFLCH-USP.1988.

Entrevista. por José Lira, Inês Bonduki, Danilo Hideki e João Sodré. Revista Desígnio. 11/12. Março de 2011.

TOZZI, Decio. Decio Tozzi. São Paulo, Editora Aleph, 2005.

WISNIK, Guilherme T. Arquitetura do Território. In Estado Crítico. Publifolha. São Paulo.

Formalismo e Tradição. Dissertação de Mestrado. FFLCH-USP. 2003. Orientador: Nicolau Sevcenko.

XAVIER, Alberto (org.). Depoimento de uma geração - arquitetura moderna brasileira. São Paulo: Cosac \& Naify, 2003. 